\title{
ДІАГНОСТИЧНЕ ЗНАЧЕННЯ ЛАБОРАТОРНИХ ПОКАЗНИКІВ ЕНДОГЕННОӤ ІНТОКСИКАЦІЇ ПРИ НЕГОСПІТАЛЬНІЙ ПНЕВМОНІї
}

\author{
๑С. М. Андрейчин, Н. А. Бількевич, Т. Ю. Чернець, Н. Я. Верещагіна, Н. А. Кавецька, \\ М. М. Руда, Н. З. Ярема, І. І. Ганьбергер, С. В. Кучер \\ ДВНЗ «Тернопільський державний медичний університет імені І. Я. Горбачевського МОЗ України»
}

РЕзюмЕ. Вступ. Синдром ендогенної інтоксикації (ЕІ) на сьогодні залишається провідним у клінічній картині негоспітальної пневмонії (НП), його вираженість співвідноситься з тяжкістю захворювання. Зміна клінічної картини пневмонії, висока частота виникнення її атипових форм, значний рівень смертності зумовлюють необхідність виявлення чітких критеріїв оцінки тяжкості патологічного процесу. В якості таких критеріїв можуть бути використані лабораторні маркери ЕІ, але вивчення їх діагностичного значення триває.

Метою дослідження стало визначення змін лабораторних показників ЕІ у хворих на НП залежно від тяжкості захворювання.

Матеріал і методи. Обстежено 175 хворих на НП, яких поділили на 3 групи за тяжкістю перебігу захворювання згідно зі шкалою Pneumonia PORT. У розпал захворювання визначали наступні маркери Еl: молекули середньої маси сироватки крові фракцій MCM $_{254}$ та MCM $_{280}$, лейкоцитарний індекс інтоксикації, токсичність сироватки крові та інтерстиціальної рідини за сім'яним тестом.

Результати. У групах пацієнтів з НП II і III класів за шкалою Pneumonia PORT було встановлено, що розвиток запалення в легенях супроводжується токсемією: значення досліджуваних параметрів у групах обстежуваних зростали пропорційно до тяжкості захворювання. Тяжкий перебіг пневмонії (IV клас) супроводжувався значним накопиченням токсинів в інтерстиції, помітним підвищенням MCM $_{280}$, а у деяких пацієнтів - парадоксальним зниженням лейкоцитарного індексу інтоксикації. Ці дані вказують на перенапруження систем детоксикації, які характерні для ендотоксикозу.

Висновок. Лабораторні маркери ендогенної інтоксикації можуть бути використані як критерії тяжкості негоспітальної пневмонії, але їх дослідження має бути комплексним, щоб характеризувати як токсемію, так і ендотоксикоз.

КлючовІ СлОВА: негоспітальна пневмонія; ендогенна інтоксикація; ендотоксикоз; маркери.

Вступ. Актуальність проблеми діагностики негоспітальної пневмонії (НП) на сучасному етапі зумовлена зміною клінічної картини захворювання, збільшенням частки нетипових їі форм, розвитком стійкості мікроорганізмів до антибіотиків, зниженням імунної резистентності населення $[2,3,5]$. Слід враховувати також періодичні спалахи грипу, при яких різко зростає захворюваність на пневмонію, тяжкий перебіг якої в даному випадку зумовлений токсичними впливами вірусу на паренхіму легень i організм в цілому $[1,6]$. Тому важливим $\epsilon$ пошук клінічних та лабораторних критеріїв прогнозування несприятливого перебігу НП $[2,5]$. У цьому контексті нового значення набула оцінка вираженості ендогенної інтоксикації (ЕI) як універсального прояву запального процесу [3].

Метою дослідження стало вивчення змін лабораторних показників ЕІ у хворих на НП залежно від тяжкості захворювання.

Матеріал і методи дослідження. Обстежено 175 хворих на НП (122 чоловіки та 53 жінки) віком від 16 до 78 років, які перебували на стаціонарному лікуванні, а також 33 здорових особи групи порівняння. В розпал хвороби у пацієнтів визначали наступні показники EI [4]: концентрацію молекул середньої маси (МСМ) сироватки крові при фотометруванні на довжині хвилі 254 i
280 нм, лейкоцитарний індекс інтоксикації (ЛІІ), токсичність сироватки крові (ТK) за сім'яним тестом, сумарну токсичність крові й інтерстиціальної рідини (CTKIP). При виборі досліджуваних показників брали до уваги, що при формуванні рівня EI токсичні метаболіти знаходяться не лише у сироватці крові, але й значною мірою депонуються в інтерстиціальній рідині, де вони безпосередньо виявляють свою патологічну дію на клітини й тканини організму хворого [4].

Результати й обговорення. Обстежених пацієнтів поділили на групи залежно від тяжкості захворювання, яку визначали згідно з шкалою бальної оцінки факторів ризику при НП (шкала PORT). I групу склали 30 осіб II класу ризику, II групу - 84 хворих III класу ризику, а III групу о6стежених - 61 пацієнт IV класу ризику. Кількісні показники El у групах обстежених наведено в таблиці 1.

При порівнянні змін досліджуваних маркерів EI виявилось, що у I групі пацієнтів концентрація $\mathrm{MCM}_{254}$ в сироватці крові була на $28,6 \%$, а у II - на $42,9 \%$ вищою від норми, відхилення абсолютних значень $\epsilon$ достовірним як відносно групи порівняння $(P<0,001)$, так і в групах обстежених $(P<0,01)$. У той же час концентрація MCM $_{280}$ в обох групах хворих не виходила за межі норми $(P>0,05)$. Зна- 
Огляди літератури, оригінальні дослідження, погляд на проблему

Таблиця 1. Показники ендогенної інтоксикації у хворих на негоспітальну пневмонію з різною тяжкістю перебігу захворювання $(\mathrm{M} \pm \mathrm{m})$

\begin{tabular}{|l|c|c|c|c|c|}
\hline Групи обстеження & МСM $_{254^{\prime}}$ ум. од. & MCM $_{280}$ ум. од. & ЛІІ & TК, \% & CTKIP, \% \\
\hline Здорові люди & $0,49 \pm 0,02$ & $0,25 \pm 0,03$ & $0,74 \pm 0,07$ & $0,20 \pm 0,10$ & $0,48 \pm 0,01$ \\
\hline I група & $0,63 \pm 0,02$ & $0,23 \pm 0,01$ & $0,74 \pm 0,04$ & $2,78 \pm 0,24$ & $3,14 \pm 0,19$ \\
$\mathrm{P}_{\mathrm{N}-1}$ & $<0,001$ & $>0,05$ & $>0,05$ & $<0,001$ & $<0,001$ \\
\hline II група & $0,70 \pm 0,01$ & $0,27 \pm 0,01$ & $1,15 \pm 0,06$ & $3,60 \pm 0,12$ & $5,00 \pm 0,55$ \\
$\mathrm{P}_{\mathrm{N}-2}$ & $<0,001$ & $>0,05$ & $<0,001$ & $<0,001$ & $<0,001$ \\
$\mathrm{P}_{1-2}$ & $<0,01$ & $<0,01$ & $<0,001$ & $<0,01$ & $<0,01$ \\
\hline III група & $0,70 \pm 0,01$ & $0,33 \pm 0,01$ & $1,44 \pm 0,12$ & $4,98 \pm 0,11$ & $8,62 \pm 0,38$ \\
$\mathrm{P}_{\mathrm{N}-3}$ & $<0,001$ & $<0,02$ & $<0,001$ & $<0,001$ & $<0,001$ \\
$\mathrm{P}_{1-3}$ & $<0,01$ & $<0,001$ & $<0,001$ & $<0,001$ & $<0,001$ \\
$\mathrm{P}_{2-3}$ & $>0,05$ & $<0,001$ & $<0,05$ & $<0,001$ & $<0,001$ \\
\hline
\end{tabular}

Примітки: 1. $\mathrm{P}_{\mathrm{N}-1}, \mathrm{P}_{\mathrm{N}-2}$ та $\mathrm{P}_{\mathrm{N}-3}$ - вірогідність відмінностей показників у групах обстежених стосовно контрольної групи; 2. $\mathrm{P}_{1-2}, \mathrm{P}_{1-3}$ та $\mathrm{P}_{2-3}$ - вірогідність відмінностей між дослідними групами.

чення ЛІІ відхилялись від показника контрольної групи лише у II групі обстежених (Р<0,001).

Більш суттєві зміни стосувались ТК: вона різко зростала відносно норми в обох групах пацієнтів пропорційно до тяжкості недуги ( $\mathrm{P}<0,001$ відносно норми, Р<0,01 у групах обстежених). При цьому суттєвої різниці вмісту токсинів в інтерстиціальній рідині та крові не виявлено: співвідношення CTKIP/TK становило 1,13 у I та 1,38 у II групах хворих.

За тяжкого перебігу НП (III група обстежених) не відмічено подальшого збільшення рівня MCM $_{254}$ відносно показника II групи (P>0,05). В той же час значно зростала концентрація $\mathrm{MCM}_{280}$, різниця була статистично значима відносно I і II груп та норми (Р<0,02-0,001). Спостерігали достовірне збільшення значення ЛІІ $(P<0,05-0,001)$ відносно інших груп обстежених. Водночас середнє квадратичне відхилення його було більшим за рахунок зниження ЛІІ менше від 0,5 у 10 хворих (15,6 \%). Таким чином, зміни показника із збільшенням тяжкості НП були різноспрямованими; зменшення ЛІІ у таких хворих слід розцінювати як ознаку виснаження клітинних механізмів детоксикації [6]. У цій групі пацієнтів ТК збільшувалась у 25,5 раза, середнє значення виявилось достовірно більшим від норми та показників інших груп хворих ( $\mathrm{P}<0,001)$. Зростала СТКІР ( $\mathrm{P}<0,001$ відносно всіх інших груп обстежених). Співвідношення СТКIP та ТК становило 1,68.

Таким чином, у групах обстежених, що відповідали II та III класам ризику, тобто за нетяжкого перебігу недуги, рівень токсемії був помірним і характеризувався зростанням концентрації MCM $_{254}$, TK при збереженні спроможності систем детоксикації (за даними MCM $_{280}$, ЛІІ). За тяжкого перебігу НП (IV клас ризику), на фоні вираженої токсемії розвинувся ендотоксикоз: різке збільшення СТKIP, співвідношення CTKIP/TK свідчить про депонування токсинів в інтерстиції, зростання концентрації МСМ280 певною мірою вказує на зниження детоксикаційної спроможності нирок. У частини пацієнтів значно зменшувався ЛІІ, що деякі автори розцінюють як виснаження клітинних механізмів детоксикації.

Висновок. Відхилення від норми досліджуваних нами показників ендогенної інтоксикації були пропорційними до тяжкості перебігу негоспітальної пневмонії, проте за тяжкого перебігу захворювання зміни ЛІІ були різноспрямованими, більшою мірою зростала токсичність інтерстиціальної рідини.

Перспективи подальших досліджень. Необхідно удосконалювати комплексну оцінку лабораторних маркерів ендогенної інтоксикації, які 6 характеризували рівень як токсемії, так і ендотоксикозу, при визначенні тяжкості перебігу негоспітальної пневмонії.

\section{ЛITЕРАТУРА}

1. Грип A (CALIFORNIA)/04/2009 (H1N1) на Закарпатті / С. М. Туряниця, М. А. Поляк, А. І. Когутич [та ін.] // Науковий вісник Ужгородського національного університету, серія «Медицина». - 2010. - Вип. 38. - С. 95-101.

2. Журавльова Л. В. Ключові питання фармакотерапії хворих на негоспітальну пневмонію / Л. В. Журавльова, О. М. Кривоносова // Практикуючий лікар. 2012. - № 3. - С. 28-34.

3. Ільюк І. А. Клінічна ефективність лікування хворих на негоспітальну пневмонію із використанням тіо- тріазоліну / І. А. Ільюк // Український пульмонологічний журнал. - 2014. - № 4. - С. 69-72.

4. Методи дослідження ендогенної інтоксикації організму : методичні рекомендації / М. А. Андрейчин, М. Д. Бех, В. В. Дем'яненко і співавт. // Мін. охорони здоров'я України. Укр. центр наукової мед. інформ. та патентно-ліцензійної роботи. - Київ, 1998. - 33 с.

5. Решетар Д. В. Негоспітальні пневмонії: деякі аспекти патогенетичних механізмів розвитку// Науковий вісник Ужгородського університету, серія «Меди- 
Огляди літератури, оригінальні дослідження, погляд на проблему

цина». - 2015. - Вип. 1 (51). - С. 246-253.

6. Фещенко Ю. І. Негоспітальна пневмонія у дорослих (етіологія, патогенез, класифікація, діагностика, антибактеріальна терапія) (проект погодження до з'їзду фтизіатрів і пульмонологів України) / Ю. І. Фещенко, О. Я. Дзюблик, О. О. Мухін // Укр. пульмонологічний журнал. - 2003. - № 1. - С. 16-29.

\section{REFERENCES}

1. Turianytsia, S.M., Poliak, M.A., \& Kohutych, A.I. (2010). Hryp A (CALIFORNIA)/04/2009 (H1N1) na Zakarpatti [Influenza A (CALIFORNIA)/04/2009 (H1N1) in Transcarpathia]. Naukovyi visnyk Uzhhorodskoho natsionalnoho universytetu, seriia "Medytsyna" - Sceintifical Journal of Uzhhorod National University, Series Medicine, 38, 95-101 [in Ukrainian].

2. Zhuravlova, L.V., \& Kryvonosova, O.M. (2012). Kliuchovi pytannia farmakoterapii khvorykh na nehospitalnu pnevmoniiu [Key questions of pharmacotherapy for patients with community-acquired pneumonia]. Praktykuiuchyi likar-Doctor Practitioner, (3), 28-34 [in Ukrainian].

3. Iliuk, I.A. (2014). Klinichna efektyvnist likuvannia khvorykh na nehospitalnu pnevmoniiu iz vykorystanniam tiotriazolinu [Clinical efficacy of treatment of patients with community-acquired pneumonia using thiotriazolin]. Ukrainskyi pulmonolohichnyi zhurnal - Ukrainian Pulmonary Journal, (4), 69-72 [in Ukrainian].

4. Andreichyn, M.A., Bekh, M.D., \& Demianenko, V.V. (1998). Metody doslidzennia endohennoi intoksykatsii orhanizmu: metodychni rekomendatsii [Methods of study of en- dogenous intoxication of an organism: methodical recommendations]. Ministry of Health of Ukraine. Ukrainian Centre of Scientific Medical Information and Patent-License Work. Kyiv [in Ukrainian].

5. Reshetar, D.V. (2015). Nehospitalni pnevmonii: deiaki aspekty patohenetychnykh makhanizmiv rozvytku [Community-acquired pneumonia: some aspects of pathogenetic mechanisms of development]. Naukovyi visnyk Uzhhorodskoho universytetu, seriia "Medytsyna" - Sceintifical Journal of Uzhhorod National University, Series Medicine, 1 (51), 246-253 [in Ukrainian].

6. Feshchenko, Yu.I., Dziublyk, O.Ya., \& Mukhin, O.O. (2003). Nehospitalna pnevmoniia u doroslykh (etiolohiia, patohenez, klasyfikatsiia, diahnostyka, antybakterialna terapiia (proekt pohodzennia do zizdu ftyziatriv i pulmonolohiv Ukrainy) [Community-acquired pneumonia in adults (etiology, pathogenesis, classification, diagnosis, antibiotic therapy) (draft agreement to the Congress of Phthysiologists and Pulmonologists of Ukraine)]. Ukr. pulmonolohichnyi zhurnal - Ukrainian Pulmonary Journal, (1), 16-29 [in Ukrainian].

\title{
ДИАГНОСТИЧЕСКОЕ ЗНАЧЕНИЕ ЛАБОРАТОРНЫХ ПОКАЗАТЕЛЕЙ ЭНДОГЕННОЙ ИНТОКСИКАЦИИ ПРИ ВНЕБОЛЬНИЧНЫХ ПНЕВМОНИЯХ
}

\author{
๑С. М. Андрейчин, Н. А. Билькевич, Т. Ю. Чернець, Н. Я. Верещагина, Н. А. Кавецкая, \\ Н. Н. Руда, Н. З. Ярема, И. И. Ганьбергер, С. В. Кучер
} ДВНЗ «Тернопольский государственный медицинский университет имени И. Я. Горбачевского МОз Украины»

PЕЗЮМЕ. Введение. Синдром эндогенной интоксикации (ЕI) В настоящее время остается ведущим в Клинической картине внебольничной пневмонии (НП), его выраженность соотносится с тяжестью заболевания. Изменение клинической картины пневмонии, высокая частота возникновения ее атипичных форм, значительный уровень смертности обусловливают необходимость выяснения четких критериев оценки тяжести патологического процесса. В качестве таких критериев могут быть использованы лабораторные маркеры ЭИ, но изучение их диагностического значения продолжается.

Целью исследования стало определение изменений лабораторных показателей ЭИ у больных ВП в зависимости от тяжести заболевания.

Материал и методы. Обследовано 175 больных ВП, которых разделили на 3 группы по тяжести течения заболевания согласно шкалы Pneumonia PORT. В разгар заболевания определяли следующие маркеры эИ: молекулы средней массы сыворотки крови фракций $\mathrm{MCM}_{254}$ и $\mathrm{MCM}_{280}$, лейкоцитарный индекс интоксикации, токсичность сыворотки крови и интерстициальной жидкости с семенным тестом.

Результаты. В группах пациентов с НП II и III классов по шкале Pneumonia PORT было установлено, что развитие воспаления в легких сопровождается токсемией: значение исследуемых параметров в группах обследуемых росли пропорционально тяжести заболевания. Тяжелое течение пневмонии (IV класс) сопровождался значительным накоплением токсинов в интерстиции, заметным повышением MCM $_{280}$ а у некоторых пациентов парадоксальным снижением лейкоцитарного индекса интоксикации. Эти данные указывают на перенапряжение систем детоксикации, которые характерны для эндотоксикоза.

Вывод. Лабораторные маркеры эндогенной интоксикации могут быть использованы в качестве критериев тяжести внебольничной пневмонии, но их исследование должно быть комплексным, чтобы характеризовать как токсемию, так и ендотоксикоз.

КЛЮЧЕВЫЕ СЛОВА: воспаление; токсемия; эндогенная интоксикация; маркеры. 

IN COMMUNITY-ACQUIRED PNEUMONIA

\section{@S. M. Andreychyn, N. A. Bilkevych, T. Yu. Chernets, N. Ya. Vereshchagina, N. A. Kavetska, M. M. Ruda, N. Z. Yarema, I. I. Hanberher, S. V. Kucher I. Horbachevsky Ternopil State Medical University}

SUMMARY. Introduction. Syndrome of endogenous intoxication (EI) nowadays remains on the leading place in manifestation of community-acquired pneumonia (CAP), and its expression correlates with the severity of the disease. Change of clinical manifestation of pneumonia, high accidence of its atypical forms as well as a significant level of mortality cause the need to find clear criteria for assessment of the pathological process severity. The laboratory markers of El may be used as such criteria, but their diagnostic importance has been steel studied.

The aim of study was to investigate changes in laboratory parameters of endogenous intoxication in patients with community-acquired pneumonia depending on the severity of the disease.

Materials and Methods. The study involved 175 patients with community-acquired pneumonia, who were divided into 3 groups according to Pneumonia PORT scale. In the midst of the disease the following laboratory markers of EI were investigated: the middle-mass molecules (fractions $\mathrm{MMM}_{254}$ and $\mathrm{MMM}_{280}$ ), leukocyte intoxication index, toxicity of blood serum and interstitial fluid according to spermatic test.

Results. It was revealed that the development of inflammation in groups of patients with II and III class according to Pneumonia PORT scale was accompanied by toxemia: the value of the studied parameters in groups of surveyed was observed to be increased in proportion to the severity of the disease. In addition, severe course of pneumonia (IV class) was followed by significant accumulation of toxins in the interstitium, marked elevation of MMM280, paradoxic decrease of leukocyte index of intoxication in some patients. These findings indicate the overstrain of detoxification systems which is characteristic of endotoxicosis.

Conclusions. Laboratory markers of endogenous intoxication can be used as criteria of severity of communityacquired pneumonia, but they need to be investigated in complex to characterize both toxemia and endotoxicosis.

KEY WORDS: community acquired pneumonia; endogenous intoxication; endotoxicosis. 